Lesya Chervona

ORCID iD 0000-0002-3036-3668

$\mathrm{PhD}$ in Philosophy, Senior Researcher,

Leading Researcher of Department for Cooperation between Universities and Society, Institute of Higher Education, National Academy of Educational Sciences of Ukraine,

9 Bastionna Str., 01014 Kyiv, Ukraine, chervona_lesya@ukr.net

Oksana Bulvinska

ORCID iD 0000-0002-6764-4340

PhD in Pedagogy, Senior Researcher, Senior Researcher of Scientific-Research Laboratory of Educology, Borys Grinchenko Kyiv University, 13-b Tymoshenko Str., 04212 Kyiv, Ukraine, o.bulvinska@kubg.edu.ua

\title{
SOCIAL AND CULTURAL DETERMINANTS OF THE UNIVERSITY SOCIAL RESPONSIBILITY
}

The development of human civilization convincingly proves to us that a person, being born in a certain historical epoch in a certain country, prepares not for life in general, but for life in specific social and cultural conditions. Analysis of the available philosophical, pedagogical, sociological literature and areas of scientific and educational research indicates that researchers focus their attention on the problem of social responsibility of modern Universities. In particular, interest in this issue has grown significantly in recent years. The activities of Universities are never limited to the training of future specialists. Universities perform the social function of reproduction and development of society and its systems through the processes of translation of cultural norms in changing historical circumstances, each time on the basis of new social relations. Although among researchers there is no consensus on the definition of social responsibility of the University and the areas of its implementation, there is a general understanding of this phenomenon as a certain obligation of a higher education institution to society. That is why it is important to realize that the social responsibility of Universities should be considered in the context of the general social and cultural dynamics of a particular society. And if there were times when the social responsibility of the University could be represented by the concept of «literacy», then modern world makes completely different demands on education in general and on understanding of the University social responsibility in particular. The social responsibility of the University to society as a social institution, its individual groups and strata, is its commitment to contribute to the solution of important social problems.

Keywords: highereducation institutions; social and cultural determinants; social function; university; university social responsibility.

https://doi.org/10.28925/1609-8595.2021.2.3

Introduction. The processes in the modern world and in Ukrainian society as well, objectively make us realize the degree of social responsibility importance by various subjects of social-historical and social-political activities.

«The discourse on University social responsibility has been spreading since the end of the XX century. At the beginning of the XXI century this issue began to be discussed especially actively. Partly this is closely related to the discussion of corporate social responsibility and its extrapolation to the modern University as a corporation, partly - to the growing role of free economic education in the modern world.
Since, the Universities have the role of social leaders able to offer solutions to economic crisis, stress relief between social-ethnic or social-cultural groups, to provide prescriptions for psychological rehabilitation, etc.» (Orzhel, 2017).

The social responsibility of the University is one of the key issues of higher education modernization and is one of the indisputable values of the European Higher Education Area, which is reflected in the regulatory and strategic documents. Thus, the social dimension of higher education has become one of the key issues of the Rome Ministerial Conference of the Member States of the European Higher Education Area (2020) and the Rome Ministerial Communiqué adopted as a result.

(C) Chervona Lesya, Bulvinska Oksana, 2021 
The activity of a modern institution of higher education cannot be limited to the training of specialists; it must have a civic commitment to the sustainable development of society (Michelsen, 2015). It is the Universities that must lead the process of creating knowledge. That would help overcome social inequality, corruption and other social problems; promote effective economic development, technological progress, as well as resource management, health protection and other options that require global participation (Turpo-Gebera O et.al, 2019).

Analysis of the available philosophical, pedagogical, sociological literature and areas of scientific and educational research shows that in recent years, researchers' attention to the problem of social responsibility of modern universities has increased significantly. Scientists from different countries (Meseguer-Sánchez et al., 2020; Tetrevova et al., 2020; Duque et al., 2019) independently conducted a systematic review and bibliometric analysis of scientific publications on this topic. In Ukraine, within the TEMPUS Project «Education for Leadership, Intelligence and Talent Development», a manual «University Social Responsibility in the Context of University Leadership: a textbook» was prepared (Orzhel, 2017). The author intensified the discourse on University social responsibility as a form of University leadership, revealed its potential as a factor in improving the institutions of higher education and social development, and provided examples of best practices in the implementation of social responsibility by universities in different countries.

The problem of studying the social responsibility of the University is determined primarily by the real needs of society, the humanization of education, improving the quality of education and upbringing. In the context of our research, we note the work of T. Keryan et al. (2020), which emphasizes that the social role of Universities cannot be considered in isolation from the social conditions of management and the internal organizational structure of the academic system. Researchers have systematized different concepts of «University - region» interaction depending on the model of the institution of higher education (Entrepreneurial University; Engaged University; Triple Helix University (University - industry government relations are generated endogenously); Sustainable University).

The purpose of the article is to substantiate the socio-cultural determinants of university social responsibility as set of interrelated economic, social and cultural attitudes to education, which define the social function of reproduction and development of society in changing historical circumstances, each time on a new material of social relations.

Research methods. The article uses theoretical analysis of scientific sources to investigate the phenomenon of university social responsibility.
Results and discussion. According to the scientists (Meseguer-Sánchez et al., 2020; Tetrevova et al., 2020), there is no established definition, as well as generally accepted areas of socially responsible activities of higher education. In our opinion, the most complete is the conceptual structure of social responsibility of the Universities. It was proposed by Spanish researchers, who, based on the analysis of scientific publications, identify 7 areas of socially responsible activities of the University: Healthy, Wellbeing, Environmental, Economic, Human, Social, Equity (Meseguer-Sánchez et al., 2020).

We understand the social responsibility of the University as the obligation of the higher education institution as a social institution to the society, its separate groups or strata. The social responsibility of the University promotes the development and consolidation of society, democratic reforms in the country, ensuring equal and equitable access to higher education, development of a more cohesive and inclusive society. All of this is happening by improving intercultural understanding, civic participation and ethical awareness, as well as solving important social issues: unemployment and social inequality; issues related to migration; growing political polarization, radicalization and violent extremism; climate change, water allocation, introduction of renewable energy sources and health care (Batechko et al., 2020).

The social responsibility of the University is largely based on fundamental ethical principles and common University values, which over the centuries have created the authority of science, revealing the moral strength of academia and the meaning of the scientists' mission in promoting ethical and civic virtues. The social prestige and efficiency of the University, the quality of education and the progress of science significantly depend on the ruling ethnic group (Chervona, Bulvinska, 2021). The social responsibility of the University to society as a social institution, its individual groups and strata, is its commitment to contribute to the solution of important social problems.

The development of human civilization convincingly proves to us that a person, being born in a certain historical epoch in a certain country, prepares not for life in general, but for life in specific social and cultural conditions. Formal education cannot overcome the influence of social and cultural environment, because it performs the social function of reproduction and development of society and its systems of life. Education is realized through the processes of translation of cultural norms in changing historical circumstances, each time on a new material of social relations. Therefore, it is necessary to realize that the social responsibility of Universities should be considered in the context of the general social and cultural dynamics of a particular society. However, it is possible to demonstrate and trace the influence of social and cultural determinants on the understanding of social responsibility concept by 
considering the social and historical dynamics of the concept evolution and requirements for education. Since the emergence of human life on earth, people have faced the problem: how and what to teach future generations so that they could survive, develop and influence the development of the world (society).

In primitive times, there was no education in its modern sense. But we can assume that such training was necessary, both at the level of physical development and at the level of certain knowledge transfer, which enabled a person to survive in a cruel world. As they developed, societies made new demands on the necessary knowledge. These requirements were formed by social, cultural and historical circumstances. For example, in the IV millennium BC with the emergence of the slaveowning state in Egypt, there were schools of priests (schools of calligraphy), which taught boys from priestly families' hieroglyphs, arithmetic, arithmetic, astronomy, features of the ancient Egyptian religious cult. All this training, which lasted ten years, was exclusively caste and religious in nature. In the third millennium BC the development of the economy in Egypt and the demands of public life, government, etc. led to the emergence of schools of scribes, which aimed to prepare for Egypt future government officials.

Ancient Greece, consisting of individual citiesstates, differed in education requirements, depending on the needs of their cities. For example, for the citizens of Sparta the main thing was the war, which was taught and prepared from childhood (it is known that physically ill children were destroyed by the Spartans; only those who were considered healthy were brought up). The main purpose of Spartan education was to train good warriors, devoted to the state, while cultural or scientific education was not recognized. At the same time, ancient Athens was a center of high spiritual culture, so the main purpose of Athenian education was to form a harmonious person, spiritually rich, morally pure and physically perfect. The idea of the harmonious development of the individual as the goal of education appeared exactly in Athens.

In the Middle Ages, at the stage of formation of religious educational systems, education was perceived as a special kind of spiritual practice. Its advantages were determined by the degree of the spiritual basis in the educational environment. The quality of such education is determined by how the individual spiritual practice is consistent with religious ideals. Progressive social development led to a certain «democratization» of religious knowledge: during the Reformation, the individual's ability to read, understand, and interpret the Bible became a general and obligatory norm of society. At about the same time, the ideas of education universality and compulsory, which have become so familiar and natural to us today, are beginning to take shape in the European public consciousness. Quality education of that period can be represented by the concept of «literacy», as the ability to read, write, count becomes a prerequisite for any career growth. Thus, «literacy» is associated not so much with the «simple» level of education, but with the achievement of public agreement on the «educational qualification» of each citizen. Around this historical period, a five-point system of individual assessment in individual subjects emerged, as well as a number of relatively independent educational practices that ensured the reproduction of the guild and class organization of society. If we try to determine the most significant aspect of educational practice, the measure of the education quality of this kind is «skill» as a special fusion of spiritual traditions, secrets of successful and effective activity, individual abilities and social need to maintain appropriate production (Lobanova, 2011).

As we can see, the social and cultural context directly affects the public awareness of the University social responsibility. Different ideas about what is the social responsibility of the University, leads to the fact that it has different requirements. And if there were times when the social responsibility of the University could be represented by the concept of «literacy», then modern world makes completely different demands on education in general and on understanding of the University social responsibility in particular.

The social and cultural situation determines the requirements for the person, which are reflected in the requirements for the University social responsibility and determine its goals. «When solving the problem of what education should be like, we should find an answer to the question about what a human should be like. The human himself or herself is the main criterion in determining the consistency or inconsistency of the education system with the needs of social development» (Ogneviuk, 2003, p. 282). The understanding of the essence of the University social responsibility and building its theoretical and methodological basis is impossible without taking into account the social and cultural situation in the country in recent decades.

Education as a social and cultural phenomenon is included in the social process and is one of the basic concepts of social reality. The social and cultural situation in Ukraine has changed significantly in recent decades. Ukraine is becoming an open country. It builds a market economy and the rule of law, increases the degree of freedom and responsibility of a person for his own well-being and for the well-being of society. In the modern world human capital is becoming the main resource for the development of any country, a factor that ensures its stability and progress. Ukraine, like any other country, needs mobile and highly qualified specialists who are able to make independent responsible decisions in the uncertainty of a rapidly changing world. Of course, this very fact makes special demands on the education system (Zinchenko, 2018).

The analysis of the directions of education modernization in Ukraine shows that the main expected changes are the achievement of a new quality 
of education, which corresponds to the main factors of modern society development (Zinchenko, 2018):

- informatization of society (setting priority to the constructing of the personal knowledge based on independent work with a variety of information);

- the formation of an open society that provides a significant expansion of human habitat and numerous intersections of individual environments;

- the formation of civil society, which increases the degree of freedom and, consequently, human responsibility in the implementation of life;

- formation of a new cultural type of personality (characteristics of which are activity, independence and responsibility of the individual);

- lifelong professionalization (which involves a person's willingness to learn and relearn throughout life). Thus, we can talk about the existing interdependence of the level of society development and social responsibility of a modern University.

From time to time society, depending on the degree of its development, reconsiders and rethinks both the priorities and the content of higher education. Thus, we cannot talk about any absolute things in education. But only about the consistency of requirements, which are determined by consensus of all stakeholders at a particular stage of society development. «The task of education is that it should be aimed at anticipating social development and subordinated to meeting the needs of all members of society. Science should be more and more focused on modelling the future, and education - on the formation of a person capable of living in it» (Ogneviuk, 2003, p. 282).

In 1995 the General Conference of UNESCO in the program document «Reform and Development of Higher Education» three main areas of higher education are identified, namely: compliance with the requirements of the time, internationalization and quality. If we consider the main approaches to the interpretation of the education quality, the international organizations, involved in standardization based on ISO 9007, a special definition is adopted. Here quality is interpreted as a set of characteristics of the object related to its ability to meet established and possible needs. As for education, the quality is usually considered not only as a result of activity, but also as a process aimed at achieving the planned results, taking into account the internal potential and external conditions of the object. Therefore, when it comes to the meaning of the concept of «education quality», there is always a clear distinction between process and result, between the levels of education and the requirements for the quality of education by consumers and customers of educational services.

Thus, we note the direct impact of social and cultural factors on education and on the understanding of the University social responsibility. However, in the context of our research, the interpretation of the concept of «education» remains important. In general, the interpretation of the concept of «education» depends on the approach to the idea of a person, although the possibility of education as a practice itself already dictates a certain approach to the idea of a person. But does this affect the content, essence, nature of a person? If in the process of education, the nature of a person is not affected, then the diversity of educational practices is determined by cultural and historical ideas about the images or patterns under which a person is brought in the process of education. In this case, the discussion revolves either around the interpretation of the concept, such as «harmoniously developed personality», or around the understanding of specific patterns. If education is able to influence human nature, then educational practice becomes anthropotechnics and falls within the scope of the moral law.

The pluralism of modern European societies creates a plurality of proposals for goals and patterns of human development in the field of education. Modern person is freer to choose the type of education that can be offered by society. Human is less limited by origin due to social dynamics and mobility; less bound by his own abilities due to high technology. People are less dependent on their mother tongue and ethnicity due to the globalization and standardization of education and the internationalization of cultural languages. A person's choice of education is limited only by his orientation in the world of values. Orientation in the world of modern values is an independent task of educational activities, in contrast to past historical situations, when values were transmitted in the process of education. But this orientation in the world of values is ensured not only in educational institutions, but also in the family, in the media, in interpersonal contacts, and so on. And when one of the most important tasks of education is removed from the sphere of educational institutions responsibility, there is a need to transform the whole society into an educational community. Thus, in general, we can consider education as a function of society that ensures the reproduction and development of society and its vital functions.

Conclusions. Over the centuries, universities have evolved significantly in their development under the influence of historical, political, social and cultural circumstances. Having overcome the millennial path of growth, the Universities of the XXI century represent a qualitatively new formation in comparison with the prototypes. The understanding of social responsibility changed over the centuries. In the modern sense, the social and cultural component of the University social responsibility is a set of interrelated economic, social and cultural attitudes to education. The presence and content of these options allow responding to the requirements of the modern society: to act productively, to develop, to organize, to renew, to change and to influence social processes. The social and cultural situation determines the requirements for the person, which are reflected in the requirements for the University social responsibility 
and determine its goals. The understanding of the essence of the University social responsibility and building its theoretical and methodological basis is impossible without taking into account the social and cultural situation in the country in recent decades. The results of the analysis prove the following: although this area of research is relatively young, numerous publications show a growing interest in the impact of higher education institutions on the economy, environmental and social development of countries all over the world. Prospects for further research are to study the students' participation in the university social responsibility.

\section{Reference}

Duque, P., Cervantes-Cervantes, L. S. (2019). Responsabilidad Social Universitaria: una revisión sistemática y análisis bibliométrico. Estudios Gerenciales, 35 (153), 451-464. https://doi.org/10.18046/j.estger.2019.153.3389

Keryan, T., Muhar, A., Mitrofanenko, T., Khoetsyan, A., Radinger-Peer, V. (2020). Towards Implementing Transdisciplinarity in Post-Soviet Academic Systems: An Investigation of the Societal Role of Universities in Armenia. Sustainability, 12, 8721. https://doi.org/10.3390/su12208721

Meseguer-Sánchez, V., Abad-Segura, E., Belmonte-Ureña, L. J., Molina-Moreno, V. (2020). Examining the Research Evolution on the Socio-Economic and Environmental Dimensions on University Social Responsibility. International Journal of Environmental Research and Public Health, 17 (13). https://doi.org/10.3390/ ijerph17134729

Michelsen, G. (2015). Policy, politics and polity in higher education for sustainable development. In Routledge handbook of higher education for sustainable development (pp. 64-79). Routledge. https://www. routledgehandbooks.com/doi/10.4324/9781315852249.ch3

Ramos-Monge, E. L., Audet, X. L., Barrena-Martínez, J. (2017). Universities as Corporate Entities: The Role of Social Responsibility in Their Strategic Management. Corporate Governance and Strategic Decision Making. http://dx.doi.org/10.5772/intechopen.69931

Rome Ministerial Communiqué 19 November 2020. http://ehea.info/Upload/Rome_Ministerial_Communique.pdf Sales, A. (ed.). (2019). Corporate Social Responsibility and Corporate Change: Institutional and Organizational Perspectives. Springer Nature. https://doi.org/10.1007/978-3-030-15407-3

Tetrevova, L., Vavra, J., and Munzarova, S. (2021). Communication of Socially-Responsible Activities by Higher Education Institutions. Sustainability, 13, 483. https://doi.org/10.3390/su13020483

Turpo-Gebera, O., Tapia Díaz, K., Zevallos, M., Carnero, R., Begazo, C. (2019). Percepciones de estudiantes de la modalidad blended learning sobre la responsabilidad social universitaria. Revista Ibéricade Sistemase Tecnologias de Informação, Associação Ibéricade Sistemase Tecnologias de Informação, E21, 368-381. http:// www.risti.xyz/issues/ristie21.pdf

Veldman, F. J. (2018). Market Driven Global Directives and Social Responsibility in Higher Education. African Journal of Business Ethics, 12 (1). https://doi.org/10.15249/12-1-168

Zinchenko, V. (2018). Humanism, enlightenment strategies and the deliberative potential of the democratic development of society. International Journal of Social Research, 2 (17), 1-14. 10.28933 / ijsr-2018-05-3001

Batechko, N. G., Bulvinska, O. I., Lokshina, O. I., Mospan, N. V., Protsenko, O. B., Sysoeva, S. O., Sokolova, I. V. (2020). Yevropejskij prostir vishoyi osviti: parametri yakosti ta ekspertizi: navchalnij posibnik [European higher education area: quality parameters and expertise: courcebook]. http://elibrary.kubg.edu.ua/id/ eprint/33934/1/N_Batechko_Posibnik_2020_NDLO.pdf

Chervona, L. Bulvinska, O. (2021). Social responsibility of universities: axiological aspects. Collection of scientific papers А'ОГОГ, 181-183. 10.36074/logos-26.02.2021.v2.55

Lobanova, S. I. (2011). Sociokulturni determinanti formuvannya modelej vihovannya ditej i molodi u Starodavnomu Rimi [Sociocultural determinants of the formation of models of education of children and youth in ancient Rome]: Extended abstract of candidate's thesis: 13.00.01. Vinnytsia State Pedagogical University.

Ogneviuk, V. O. (2003). Osvita v sistemi cinnostej stalogo lyudskogo rozvitku [Education in the system of values of sustainable human development]. Knowledge of Ukraine.

Orzhel, O. (2017). Universitetska socialna vidpovidalnist u konteksti universitetskogo liderstva: navchalnij posibnik [University social responsibility in the context of university leadership: a textbook]. Priorities.

\section{Лiтература}

Duque P., Cervantes-Cervantes L. S. Responsabilidad Social Universitaria: una revisión sistemática y análisis bibliométrico. Estudios Gerenciales. 2019. № 35 (153). P. 451-464. DOI: https://doi.org/10.18046/j. estger.2019.153.3389

Keryan T., Muhar A., Mitrofanenko T., Khoetsyan A., Radinger-Peer V. Towards Implementing Transdisciplinarity in Post-Soviet Academic Systems: An Investigation of the Societal Role of Universities in Armenia. Sustainability. 2020. № 12. 8721. DOI: https://doi.org/10.3390/su12208721

Meseguer-Sánchez V., Abad-Segura E., Belmonte-Ureña L. J., Molina-Moreno V. Examining the Research Evolution 
on the Socio-Economic and Environmental Dimensions on University Social Responsibility. International Journal of Environmental Research and Public Health. 2020. № 17 (13). DOI: https://doi.org/10.3390/ ijerph17134729

Michelsen G. Policy, politics and polity in higher education for sustainable development. In Routledge handbook of higher education for sustainable development. Abingdon, UK: Routledge, 2015. P. 64-79. DOI: https://www. routledgehandbooks.com/doi/10.4324/9781315852249.ch3

Ramos-Monge E. L., Audet X. L., Barrena-Martínez J. Universities as Corporate Entities: The Role of Social Responsibility in Their Strategic Management. Corporate Governance and Strategic Decision Making. 2017. DOI: http://dx.doi.org/10.5772/intechopen.69931

Rome Ministerial Communiqué 19 November 2020. URL: http://ehea.info/Upload/Rome_Ministerial_ Communique.pdf (дата звернення: 15.05.2021).

Sales A. (ed.). Corporate Social Responsibility and Corporate Change: Institutional and Organizational Perspectives. Springer Nature, 2019. DOI: https://doi.org/10.1007/978-3-030-15407-3

Tetrevova L., Vavra J., and Munzarova S. Communication of Socially-Responsible Activities by Higher Education Institutions. Sustainability. 2021. № 13. 483. DOI: https://doi.org/10.3390/su13020483

Turpo-Gebera O., Tapia Díaz K., Zevallos M., Carnero R., Begazo C. Percepciones de estudiantes de la modalidad blended learning sobre la responsabilidad social universitaria. Revista Ibéricade Sistemase Tecnologias de Informação, Associação Ibéricade Sistemase Tecnologias de Informação. 2019. E21. P. 368-381. http://www. risti.xyz/issues/ristie21.pdf

Veldman F. J. Market Driven Global Directives and Social Responsibility in Higher Education. African Journal of Business Ethics. 2018. № 12 (1). DOI: https://doi.org/10.15249/12-1-168

Zinchenko V. Humanism, enlightenment strategies and the deliberative potential of the democratic development of society. International Journal of Social Research. 2018. № 2 (17). P. 1-14. DOI: 10.28933 / ijsr-2018-05-3001

Батечко Н. Г., Бульвінська О. І., Локшина О. І., Мосьпан Н. В., Проценко О. Б., Сисоєва С. О. (ред.)., Соколова I. В. (2020). Європейський простір вищої освіти: параметри якості та експертизи: навчальний посібник. Київ, 2020. 194 c. http://elibrary.kubg.edu.ua/id/eprint/33934/1/N_Batechko_Posibnik_2020 NDLO.pdf

Червона Л., Бульвінська О. Соціальна відповідальність університетів: аксіологічні аспекти. Збірник наукових праць АОГОГ. 2021. С. 181-183. DOI: https://doi.org/10.36074/logos-26.02.2021.v2.55

Лобанова С. І. Соціокультурні детермінанти формування моделей виховання дітей і молоді у Стародавньому Римі: автореф. дис. ... канд. пед. наук: 13.00.01. Вінниця: ВДПУ імені Михайла Коцюбинського, 2011. 22 с.

Огнев'юк В. О. Освіта в системі цінностей сталого людського розвитку. Київ: Знання України, 2003. 450 с.

Оржель О. Університетська соціальна відповідальність у контексті університетського лідерства : навчальний посібник. Київ : Пріоритети, 2017. 40 с.

\title{
СОЦІОКУЛЬТУРНІ ДЕТЕРМІНАНТИ СОЦІАЛЬНОЇ ВІДПОВІДАЛЬНОСТІ УНІВЕРСИТЕТІВ
}

\author{
Червона Леся, кандидат філософських наук, старший науковий співробітник, \\ провідний науковий співробітник відділу взаємодії університетів та суспільства, \\ Інститут вищої освіти НАПН України, \\ вул. Бастіонна, 9, 01014 Київ, Україна, chervona_lesya@ukr.net
}

Бульвінська Оксана, кандидат педагогічних наук, старший науковий співробітник, старший науковий співробітник науково-дослідної лабораторії освітології,

Київський університет імені Бориса Грінченка,

вул. Тимошенка, 13-б, 04212 Київ, Україна, o.bulvinska@kubg.edu.ua

Розвитоклюдськоїиивілізаиї̈ереконливодоводить,щолюдина,народжуючисьвпевнуісторичнуепоху в певній країні, готується не до життя загалом, а до життєдіяльності в конкретних соціокультурних умовах. Аналіз наявної філософської, педагогічної, соціологічної літератури та напрями наукових $i$ освітніх досліджень свідчать, що в останні роки помітно посилилася увага дослідників до проблеми соціальної відповідальності сучасних університетів. Діяльність університетів ніколи не обмежувалася лише підготовкою майбутніх фахівиів, а виконувала соціальну функцію відтворення і розвитку самого соціуму і систем його життєдіяльності, реалізуючись через процеси трансляції культурних норм у змінюваних історичних обставинах, щоразу на новому матеріалі сочіальних відносин. Незважаючи на те, що серед дослідників відсутня єдність щодо визначення соціальної відповідальності університету 
та сфер ї̈ здійснення, є загальне розуміння ї̈ як певного зобов'язання закладу вищої освіти перед суспільством. Саме тому важливо усвідомлювати, що сочіальну відповідальність університетів потрібно розглядати в контексті загальної соціокультурної динаміки розвитку конкретного суспільства. У сучасному розумінні соціокультурна складова соціальної відповідальності університетів є сукупністю взаємопов'язаних економічних, соціальних і культурних відносин до освіти, наявність та зміст яких дозволяє їй (освіті) відповідним чином відповідати на вимоги соціуму і не тільки продуктивно діяти, але і саморозвиватися, самоорганізовуватися, оновлюватися, змінюватися і впливати на соціальні процеси. Соціальна відповідальність університету як соціального інституту перед суспільством, його окремими групами і прошарками полягає в його зобов'язанні сприяти своєю діяльністю розв'язанню важливих сочіальних проблем.

Ключові слова: заклади вищої освіти; соціальна відповідальність університету; соціальна функція; сочіальні та культурні детермінанти; університет.

\section{СОЦИОКУЛЬТУРНЫЕ ДЕТЕРМИНАНТЫ СОЦИАЛЬНОЙ ОТВЕТСТВЕННОСТИ УНИВЕРСИТЕТОВ}

Червона Леся, кандидат философских наук, старший научный сотрудник, ведущий научный сотрудник отдела взаимодействия университетов и общества, Институт высшего образования НАПН Украины, ул. Бастионная, 9, 01014 Киев, Украина, chervona_lesya@ukr.net

Бульвинская Оксана, кандидат педагогических наук, старший научный сотрудник, старший научный сотрудник научно-исследовательской лаборатории освитологии,

Киевский университет имени Бориса Гринченко,

ул. Тимошенко, 13-б, 04212 Киев, Украина, o.bulvinska@kubg.edu.ua

Развитие человеческой чивилизации убедительно доказывает, что человек, рождаясь в определенную историческую эпоху в определенной стране, готовится не кжизни в целом, а к жизнедеятельности в конкретныхсочиокультурныхусловиях.Анализимеющейсяфилософской,педагогической,сочиологической литературы и направления научных и образовательных исследований свидетельствуют, что в последние годы заметно усилилось внимание исследователейк проблеме социальной ответственности современных университетов. Деятельность университетов никогда не ограничивалась только подготовкой будущих спещиалистов, а выполняла социальную функцию воспроизводства и развития самого социума и систем его жизнедеятельности, реализуясь через процессы трансляции культурных норм в изменяющихся исторических обстоятельствах, каждый раз на новом материале социальных отношений. Несмотря на то, ито среди исследователей отсутствует единство в определении социальной ответственности университета и сфер ее осуществления, есть общее понимание ее как определенного обязательства высшего учебного заведения перед обществом. Именно поэтому важно понимать, что социальную ответственность университетов нужно рассматривать в контексте общей социокультурной динамики развития конкретного общества.

Ключевые слова: высшие учебные заведения; сочиальная ответственность университета; социальная функиия; социальные и культурные детерминанты; университет. 